LEPORE, M.J. (1958) Long-term or maintenance adrenal steroid therapy in non-tropical sprue. American Journal of Medicine, 25, 381.

London, D.R., BAmforth, J. \& CREAmer, B. (1961) Steatorrhoea presenting with gastrointestinal protein loss. Lancet, ii, 18.

MacDonald, W.C., Brandborg, L.L., Flick, A.L., Trier, J.S. \& Rubin, C.E. (1964) Studies of coeliac sprue. IV. The response of the whole length of the small bowel to a gluten-free diet. Gastroenterology, 47, 573.

Pink, I.J. \& Creamer, B. (1967) Response to a gluten-free diet of patients with the coeliac syndrome. Lancet, $\mathbf{i}, 300$.

SCHEIN, J. (1947) Syndrome of non-tropical sprue with hitherto undescribed lesions in the small intestine. Gastroenterology, 8, 438.
SHINER, M. (1963) Effect of a gluten-free diet in seventeen patients with idiopathic steatorrhoea: a follow-up study. American Journal of Digestive Diseases, 8, 969.

Stewart, J.S., Pollock, D.J., Hoffbrand, A.V., Mollin, D.L. \& Booth, C.C. (1967) A study of proximal and distal intestinal structure and absorptive function in idiopathic steatorrhoea. Quarterly Journal of Medicine, 36, 425.

WAlker-Smith, J.A., Skyring, A.P. \& Mistilis, S.P. (1967) Use of ${ }^{51} \mathrm{CrCl}_{3}$ in the diagnosis of protein-losing enteropathy. Gut, 8, 166.

Wall, A.J., Douglas, A.P., Booth, C.C. \& Pearse, A.G.E. (1970) Response of the jejunal mucosa in adult coeliac disease to oral prednisolone. Gut, 11, 7 .

Weinstein, W.M., Saunders, D.R., Tytgat, G.N. \& Rubin, C.E. (1970) Collagenous sprue-an unrecognised type of malabsorption. New England Journal of Medicine, 283, 1297.

\title{
Ankylosing spondylitis and auto-immunity
}

\author{
G. O. CowaN \\ M.B., M.R.C.P., M.R.C.P.E., D.T.M.\&H. \\ British Military Hospital, Rinteln B.F.P.O.29
}

\begin{abstract}
Summary
A case of ankylosing spondylitis is described in which a relationship with gastric and endocrine autoimmunity could be demonstrated.
\end{abstract}

\section{Case report}

C.B., a Caucasian male aged 46, presented with a history for 4 months of general malaise, night sweats, loss of $8 \mathrm{~kg}$ in weight and deep constant pain in both hips, lower central back and upper lateral chest, with associated morning stiffness and considerable loss of spinal mobility. He admitted to occasional slight backache for 10 years, but he had never previously sought treatment for it. He had no peripheral joint pain and no gastro-intestinal or urinary symptoms.

On examination, he had marked loss of spinal mobility, being unable to rise from a supine position without first rolling prone. There was marked tenderness over both sacro-iliac joints and generally over his spine and rib-cage. Cervical spinal mobility was good. There was no evidence of peripheral joint disease and examination of his central nervous system, abdomen, heart and eyes was normal. Chest expansion was limited to $2 \mathrm{~cm}$, but his peak expiratory flow rate was $410 \mathrm{l} / \mathrm{min}$. Rectal examination revealed a slightly enlarged and markedly tender prostate gland, especially in the medial lobe.

Investigations. Significant abnormal findings were: ESR (Westergren) $85-120 \mathrm{~mm} / \mathrm{hr}$; total serum proteins $7.4 \mathrm{~g} / 100 \mathrm{ml}$, albumin $3.0 \mathrm{~g} / 100 \mathrm{ml}$, globulin
$4.4 \mathrm{~g} / 100 \mathrm{ml}$, with no abnormality on paper electrophoresis but moderately raised IgG level $(1.7 \mathrm{~g} /$ $100 \mathrm{ml}$ ). Auto-antibodies (Doniach, personal communication): thyroglobulin tanned cell agglutinationo negative; cytoplasmic immunofluorescent antibodies positive (CFT 1 in 4); gastric parietal cell antibodies strongly positive; adrenal antibodies negative; antinuclear factor negative.

Serum $\mathrm{B}_{12} 125 \mathrm{pg} / \mathrm{ml}$. (Euglena gracilis). Schilling test $\left(1 \mu \mathrm{g}\right.$ of $\left.58 \mathrm{Co} \mathrm{B}_{12}\right)$ less than $1 \%$ absorbed in $24 \mathrm{hr}$ without intrinsic factor; $25 \%$ absorbed in $24 \mathrm{hr}$ with intrinsic factor. Maximal histamine test $(0.04 \mathrm{mg} / \mathrm{kg})$ : no free acid in gastric contents before or in $1 \mathrm{hr}$ after injection. Gastric biopsy: marked thinning of the mucous membrane, shortening of gastric glands, marked plasma cell and lymphocyte infiltration of lamina propria.

Haemoglobin $13.2 \mathrm{~g} / 100 \mathrm{ml}$, PCV $42 \%$. Sternal marrow biopsy: normoblastic erythropoiesis but reduced stained iron. Serum iron $100 \mu \mathrm{g} / 100 \mathrm{ml}$. $X$-rays: chest and skull normal. Lumbar spine: marked bilateral sacro-iliac joint sclerosis with anterior and posterior lumbar intervertebral spondylitis and syndesmophytes. Slight posterior intervertebral sclerosis in upper dorsal spine. Barium meal showed mild atrophic gastritis and barium enema was normal. Normal results were obtained for the following investigations: blood urea, serum uric acid, calcium, inorganic phosphate, acid and alkaline phosphatase, cholesterol, folate; liver function tests; VDRL, RPCFT, RA and LE latex, 
SCAT (Rose-Waaler), Widal, brucellar antibodies, ECG, stool examination for occult blood and parasitic ova; thyroid function (Thyopac T3-105); glucose tolerance test; plasma cortisol.

Examination of routine mid-stream urine specimens showed no abnormality; after prostatic massage the urine contained large numbers of pus cells but was sterile on routine culture.

He was treated with oral Indomethacin $25 \mathrm{mg}$ t.i.d. which produced rapid and complete remission of his skeletal symptoms. He has remained well on this treatment, but has been unable to reduce the dosage without recurrence of back pain and stiffness, and his ESR remains elevated at $75 \mathrm{~mm} / \mathrm{hr} 6$ months after starting treatment. He has also been given intramuscular vitamin $B_{12} 1000 \mu \mathrm{g}$ monthly, and courses of ampicillin and sulphonamide, which have reduced his prostatic tenderness and post-massage pyuria.

The patient was unable to produce medical details of his parents, but both had died in their seventies. He knew of no family history of joint disease, thyroid disease, or pernicious anaemia. His only sibling, a male aged 57, had been found at the age of 49 to have Addison's disease and radiological but asymptomatic sacroiliitis. He later developed thyrotoxicosis and diabetes mellitus and a positive result for gastric parietal cell antibodies, but his serum $B_{12}$ level was normal. Tests for thyroid and adrenal antibodies were negative (Mahler, personal communication).

\section{Discussion}

Ankylosing spondylitis has not generally been regarded as one of the interrelated group of autoimmune diseases with organ-specific antibodies, which includes Hashimoto's disease, thyrotoxicosis, atrophic gastritis, diabetes mellitus, Addison's disease, and hypoparathyroidism (Turk, 1969; Irvine et al., 1970). Although Whittingham et al. (1971) associate rheumatoid arthritis and ulcerative colitis with these diseases, they found no correlation with ankylosing spondylitis, despite the known relationship between ulcerative colitis and ankylosing spondylitis (Acheson, 1960; Steinberg \& Storey, 1957; Bennett, 1971). There is general agreement on the absence of significant anti-nuclear antibodies in the serum (Ritchie, 1967) and synovial fluid (Macsween et al., 1967) of patients with ankylosing spondylitis, but conflicting evidence on the signifi- cance of increased serum immunoconglutinins; Bienenstock \& Block (1967) reporting significant increases in rheumatoid arthritis, ankylosing spondylitis, acute gout, Hashimoto's disease, Sjogren's syndrome and systemic lupus erythematosus, a group in which they find the presence of gout and ankylosing spondylitis 'unexpected'. Ankylosing spondylitis has also been associated with antibodies to joint tissue (Felsch, 1969) and with chronic prostatitis (Mason et al., 1958) and prostatic autoantibodies (Grimble \& Lessof, 1965).

The patient described shares with his only sibling sacro-iliitis and gastric parietal cell antibodies. The patient has atrophic gastritis, symptomatic ankylosing spondylitis and sub-acute prostatitis and his sibling Addison's disease, thyrotoxicosis and diabetes mellitus, thus implying a more direct relationship in this instance between ankylosing spondylitis, prostatitis and the thyrogastric and polyendocrine group of auto-immune diseases.

\section{References}

ACHESON, E.D. (1960) An association between ulcerative colitis, regional enteritis, and ankylosing spondylitis. Quarterly Journal of Medicine, 29, 489.

BennetT, R. (1971) Familial spondylitis. Proceedings of the Royal Society of Medicine, 64, 663.

BiENENSTOCK, J. \& BLOCH, K.J. (1967) Immunoconglutinin in various rheumatic disease and certain diseases suspected of an auto-immune pathogenesis. Arthritis and Rheumatisn $10,187$.

FelsCH, G. (1969) Auto-immunological processes in rheu matism. Zeitschrift für die gesamte innere und ihre brenzgebiete, 24-10, 145.

Grimble, A. \& Lessof, M.H. (1965) Anti-prostate antibodies in arthritis. British Medical Journal, 2, 263.

Irvine, W.J., Clarke, B.F., Scarth, L., Cullen, D.R. \& DunCAN, L.J.P. (1970) Thyroid and gastric auto-immunity in diabetes mellitus. Lancet, $\mathbf{i}, 163$.

Macsween, R.N.M., Dalakos, T.K., Jasani, M.K., Wilson, M.E., Boyle, J.A., Buchanan, W.W. \& Goudie, R.B (1967) Antinuclear factors in synovial fluids. Lancet, i, 312.

Mason, R.M., Murray, R.S., OAtes, J.K. \& Young, A.C. (1958) Prostatitis and ankylosing spondylitis. British Medical Journal, 1, 748.

RITCHIE, R. (1967) The clinical significance of titred antinuclear antibodies. Arthritis and Rheumatism, 10, 544.

SteInberG, V.L. \& Storey, G. (1957) Ankylosing spondylitis and chronic inflammatory lesions of the intestines. British Medical Journal, 2, 1157.

TURK, J.L. (1969) Immunology in Clinical Medicine, pp. 154 et seq. Heinemann, London.

Whittingham, S., Mathews, J.D., Mackay, I.R., STocks, A.E., UnGaR, B. \& MARTIN, F.I.R. (1971) Diabetes mellitus, auto-immunity and ageing. Lancet, i, 763. 